\title{
Yield Ability and Yield Stability, the Effective Tools Through Selection Procedure of Classified Wheat (Triticum aestivum) Crosses
}

\author{
Charalampos A. Gogas ${ }^{1} \&$ Metaxia Koutsika-Sotiriou ${ }^{1}$ \\ ${ }^{1}$ Aristotle University of Thessaloniki, Faculty of Agriculture, Laboratory of Genetics and Plant Breeding, \\ Thessaloniki, Greece \\ Correspondence: Charalampos A. Gogas, Aristotle University of Thessaloniki, Faculty of Agriculture, Laboratory \\ of Genetics and Plant Breeding, Thessaloniki, Greece. Tel: 30-231-121-1877 E-mail: hgogas@yahoo.com
}

Received: November 15, 2013 Accepted: December 13, 2013 Online Published: January 15, 2014

doi:10.5539/jas.v6n2p90 URL: http://dx.doi.org/10.5539/jas.v6n2p90

\begin{abstract}
Early generation selection in wheat breeding (Triticum aestivum), for stable high yielding genotypes, has been attempted using various parameters. The aim of the present study was the selection of genetic parameters that could be used for the assessment of crosses in the selection procedure. The experiments were conducted at the National Agricultural Research Foundation and the research farms of the Aristotle University of Thessaloniki for four growing seasons. Four out of ten crosses were chosen, based on a set of evaluation criteria estimating productivity and stability. Positive general combining ability of the parents was a prerequisite for any cross to remain in the selection procedure. The cross Oropos x Acheloos was ranked first in F1 and exhibited significant heterobeltiosis from F2 to F4 generation, producing elite F5 lines which yielded $45.05 \%$ at the best check. The ranking of the rest of the crosses in F1 remained the same in F5 generation showing that phenotyping achieved genotyping owing to isolation environment and high selection pressure. Genetic variance per cross gave a reliable estimation of the stability of the crosses through the segregating generations with Oropos $\mathrm{x}$ Acheloos being the less affected cross by environmental factors. It was concluded that early generation selection can successfully produce elite F5 lines, with an appropriate methodology which estimates productivity and stability, heterotic effects and the general combining ability of the parents.
\end{abstract}

Keywords: bread wheat, heterosis, general combining ability, genetic variance $\operatorname{cross}^{-1}$, early generation selection

\section{Introduction}

Combined improvement for stable and high yield through breeding is faced at first, with the challenge of selecting an appropriate breeding method and, second, with choosing criteria such as yield performance per se, genetic relationship matrix, heterotic patterns, and the usefulness of derived population (Lamkey, Schnicker, \& Melchinger, 1995; Schnell, 1983) etc, that would help the breeder to identify among a large number of crosses those most likely to yield elite lines. The above procedure must be handled in a way that may increase the precision of phenotyping, thus, maximizing selection efficiency and saving time and effort.

It has been pointed out that on testing early generations, the adverse effects of competition obscure the evaluation data (Hinson \& Hanson, 1962; Khalifa \& Qualest, 1975; Shebeski \& Evans, 1973). The proposed honeycomb methodology for the evaluation of quantitative traits of widely-spaced single plants under optimal field conditions minimizes the effects of competition and maximizes selection efficiency (Fasoulas, 1977; Fasoula, 2013). Therefore, the individual plant performance, as a unit of evaluation and selection, corresponds with the genotypic level of high and stable crop yield and delineates the conditions that enhance selection efficiency in plant breeding (Koutsika-Sotiriou \& Traka-Maurona, 2008).

Heterotic patterns are commonly recognized as heterosis over the better parent (heterobeltiosis), or heterosis over the mid parent (relative heterosis) (Fonseca \& Patterson, 1968), or as standard heterosis (Virmani, 1994) referring to the comparison of the F1 with the mean yield of broadly cultivated varieties at a region. Heterosis in F1 and F2 generation, as a criterion for the identification of promising crosses, constitutes the standard breeding practice which dominates every breeding procedure (Nass, 1979; Fasoulas, 1988; Roupakias et al., 1997; Gouli-Vardinoudi \& Koutsika-Sotiriou, 1999; Singh, Sharma, \& Sain, 2004; Kotzamanidis, Lithourgidis, Mauromatis, Chasioti \& Roupakias, 2008). The use of heterotic patterns promoted high-yielding crosses in F1 and F2 generation (Nass, 1979). Besides, the criterion of the proposed mean yield of F1 and F2 as a prediction criterion (Roupakias et al., 
1997) was successfully applied in barley (Kotzamanidis \& Roupakias, 2004) and in durum wheat (Kotzamanidis et al., 2008). At this point, it may be added that in maize breeding, the main criterion for choosing an F2 as source material from a number of single-cross hybrids is the tolerance to inbreeding depression, an indication of possessing desirable load of additive genes (Hallauer \& Miranda, 1995). Another parameter, revealing the genotypic profile of a parent variety, is the general or specific combining ability, which along with heterosis aims at the discrimination of promising material (Ali Avchi, 2005; Papapdopoulos, Tokatlidis, Tamoutsidis, Koutsika-Sotiriou \& Koutroubas, 2007). Therefore, it could be rather conducive to the breeder's task if the performance of late generations (F5 and further) could be predicted efficiently from the early generations performance (F1 and F2), even though the choice of the appropriate evaluation criteria is yet to be decided.

The present work elaborates on presenting a framework of genetic parameters for ranking a series of crosses in order to facilitate the common plant breeder's effort to develop varieties. Particularly, the effectiveness of parameters such as: (i) heterotic patterns, (ii) productivity and stability indexes and (iii) additive/dominant effects are being tested, aiming at identifying a number of crosses from which a sample of certain stability and yield ability will enter the selection procedure, facilitating a constant turnover of the varieties.

\section{Method}

Six bread wheat varieties (Acheron, Yecora-E, Nestos, Orfeas, Oropos, Acheloos) were crossed to produce 10 F1 `s. All the varieties were developed by the Cereal Institute of Thessaloniki and were chosen on the basis of their performance and stability in the Mediterranean environment. The characteristics of the cultivars used are shown in Table 1.

Table 1. Pedigree and agronomic traits of the six cultivars used in the crosses

\begin{tabular}{|c|c|c|c|}
\hline Cultivar & Pedigree & Agronomic characteristics & Breeder(s) \\
\hline Acheron & $\begin{array}{l}\text { Pedigree selection of the cross Kal-Bb x } \\
\text { Cj 71"S"/Hork"S" (Translocation } \\
\text { 1BL/1RS) }\end{array}$ & $\begin{array}{l}\text { Tillering: Moderate to } \\
\text { extensive } \\
1000 \text { grains weight: } 35 \pm 5 \mathrm{~g} \\
\text { Resistance to lodging: Very } \\
\text { Resistant } \\
\text { Yield: } 5800 \pm 600 \mathrm{~kg} / \mathrm{ha} \\
\text { Type: Spring }\end{array}$ & D. Gogas and S. Stratilakis \\
\hline Yecora-E & $\begin{array}{l}\text { Selection within CIMMYT`s cultivar } \\
\text { Yecora- } 70\end{array}$ & $\begin{array}{l}\text { Tillering: Moderate } \\
1000 \text { grains weight: } 45 \pm 5 \mathrm{~g} \\
\text { Resistance to lodging: } \\
\text { Resistant } \\
\text { Yield: } 5500 \pm 600 \mathrm{~kg} / \mathrm{ha} \\
\text { Type: Spring }\end{array}$ & $\begin{array}{l}\text { Cereal Institute and S. Skorda with } \\
\text { partitipation in enrichment, } \\
\text { description and registration from D. } \\
\text { Gogas and S. Stratilakis }\end{array}$ \\
\hline Nestos & $\begin{array}{l}\text { Pedigree selection for four successive } \\
\text { generations (F5 to Fm) within the } \\
\text { INIA66R//Hbgn/ drc material of Oregon } \\
\text { State University }\end{array}$ & $\begin{array}{l}\text { Tillering: Medium - rich } \\
1000 \text { grains weight: } 38 \pm 2 \\
\text { Resistance to lodging: Very } \\
\text { Resistant } \\
\text { Yield: } 6000 \pm 500 \\
\text { Type: Multi type }\end{array}$ & D. Gogas and S. Stratilakis \\
\hline Orfeas & $\begin{array}{l}\text { Selection within naturally mutated lines } \\
\text { of the cultivar Nestos (1BL/1RS } \\
\text { Translocation). }\end{array}$ & $\begin{array}{l}\text { Tillering: Satisfactory } \\
1000 \text { grains weight }(\mathrm{g}): 33 \pm 2 \\
\mathrm{~g} \\
\text { Resistance to lodging: Very } \\
\text { Resistant } \\
\text { Yield: } 6000 \pm 500 \mathrm{Kg} \text { / ha } \\
\text { Type: Spring }\end{array}$ & Cereal Institute and D. Gogas \\
\hline Oropos & $\begin{array}{l}\text { Pedigree selection of the cross S. Cerros' } \\
\text { YG-3927 }\end{array}$ & $\begin{array}{l}\text { Medium Tillering } \\
1000 \text { grains weight: } 35 \pm 5 \mathrm{~g} \\
\text { Resistance to lodging: } \\
\text { Resistant } \\
\text { Yield: } 5000 \pm 500 \mathrm{~kg} / \text { ha } \\
\text { Type: Spring }\end{array}$ & Cereal Institute and D. Gogas \\
\hline Acheloos & $\begin{array}{l}\text { Pedigree selection of the cross YГ-5143 x } \\
\text { YГ-3615 (Siete CERROS - T66xNIKH) }\end{array}$ & $\begin{array}{l}\text { Tillering: Moderate } \\
1000 \text { grains weight: } 36 \pm 2 \mathrm{~g} \\
\text { Resistance to lodging: Good } \\
\text { Yield: } 6500 \pm 400 \mathrm{~kg} / \text { ha } \\
\text { Adaptability: Special for } \\
\text { fertile soils }\end{array}$ & $\begin{array}{l}\text { Cereal Institute, D. Gogas and S. } \\
\text { Stratilakis }\end{array}$ \\
\hline
\end{tabular}


The experiments were carried out for three growing seasons (F1-F3) at the farm of the Cereal Institute of Thessaloniki (latitude $40^{\circ} 32^{\prime} \mathrm{N}$, longitude $23^{\circ} 00^{\prime} \mathrm{E}$, elevation $15 \mathrm{~m}$ ) and for two growing seasons (F4-F5) at the farm of Aristotle University of Thessaloniki at a distance of $1 \mathrm{~km}$. The selection experiments, F1 to F4 generation, were established according to the pattern of honeycomb design (Fasoulas, 1973; Fasoulas \& Fasoula, 2000).

An interplant spacing of $1 \mathrm{~m}$ (plant density $1.16 \mathrm{~m}^{-2}$ ) between each plant and between rows was used. To ensure one plant at each position three kernels were sown per position. Five weeks after sowing, all positions were thinned to a single plant. A few days before threshing all plants were tagged for identification. Threshing occurred in the field and individual plant yield was recorded $\left(\mathrm{g}\right.$ plant $\left.{ }^{-1}\right)$. All experiments were subjected to growing conditions promoting high yields.

The evaluation experiment of the selected lines of the F5 generation was established under solid stand and a randomized complete block design (RCBD) consisting of three replications was used. The plots consisted of seven rows $0.60 \mathrm{~m}$ long, spaced $25 \mathrm{~cm}$ apart (a total area of $1 \mathrm{~m}^{2}$ per plot) from which only the five central rows were harvested. For each plot $18 \mathrm{~g}$ of seed were used and appropriate agronomic practices were done timely to achieve good crop stand. Threshing occurred in the field and seeds from each plot were weighted to determine yield (g plot $\left.^{-1}\right)$.

\subsection{Pre-Selection of the Classified Group of Crosses}

Ten F1 crosses and their parents were evaluated for grain yield in an R-16 honeycomb design. A total of 480 single plants were evaluated with 30 replications per entry. Also, their F2 generation was evaluated in solid stand with their parents in pre-selecting manipulations (Gogas \& Koutsika-Sotiriou, 2012). Three groups of evaluation criteria were used: a) Heterosis patterns, b) Productivity and stability and c) General Combining Ability (GCA) following Griffing's (1956) estimates. Four crosses were selected according to the assessment of yield ability and stability: the highest one, two with medium values and one with the lowest value. In this way from a total of 10 crosses, four crosses with classified yield ability and stability were selected: Oropos x Acheloos (OxA), Yecora $\mathrm{x}$ Oropos (YxO), Yecora $x$ Acheloos (YxA) and Orfeas x Oropos (OxO). Selection intensity was $2.7 \%$ i.e. a given plant was compared with 36 plants in the grid (moving ring Figure 1). For single plant evaluation Plant prognostic equation (p-PE) was applied where the yield ability and stability were co-considered, according to Fasoula (2013). Within each of the four crosses three higher yielding F1 plants (in p-PE) were selected. 
F1

\section{generation}

\section{Evaluation of $10 \mathrm{~F} 1$ 's with six checks-parents in isolation environment (honeycomb design selection intensity $2.7 \%$ )}

\section{F2}

\section{generation}

Evaluation of 3 families
of each cross with 4
checks-parents

\section{F3 - F4}

\section{generations}

Evaluation of 3 families
in each $F_{3}$ and $F_{4}$ in an
$R-16$ honeycomb
design with 4 checks-
parents

F5

\section{generation}

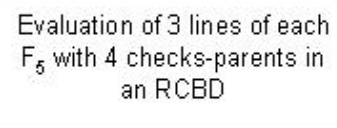

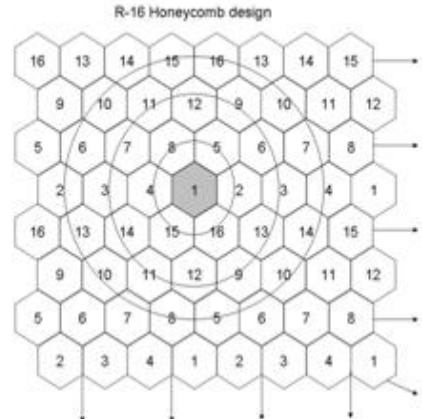

Choice of $4 \mathrm{~F} 1$ 's with degraded yield ability and stability i.e. high medium and low i.e:

1. Oropos $\times$ Acheloos (OxA)

2. Yecora $x$ Oropos $(\mathrm{Y} \times \mathrm{O})$

3. Yecora $x$ Acheloos $(Y \times A)$

4. Orfeas $\times$ Oropos $(\mathrm{O} \times \mathrm{O})$

Moving ring selection intensity

6 plants $\rightarrow 16,67$ \%

12 plants $\rightarrow 8,34$ \%

18 plants $\rightarrow 5,56$ \%

Applied methodology: pedigree with truncation selection in isolation environment (selection intensity $1.04 \%$ )
Applied methodology pedigree with truncation selection in isolation environment (selection intensity $1.85 \%$ in $\mathrm{F}_{3}$ and $2.5 \%$ in $\mathrm{F}_{4}$ )

Figure 1. The followed breeding schedule

\subsection{Evaluation of F2-F5 Generations}

For the four classified crosses, seed from each of the three plants of $F 1$ was sown as an independent entry in an R-16 honeycomb design (Figure 1), with the four parent-varieties used as checks ( 4 crosses $x 3$ plants per cross i.e. 12 entries, plus 4 parents a total of 16 entries). From the F2 to the F4 generation pedigree truncation selection was applied with an intensity of selection $1.04 \%$ for F2 ( 3 out of 288 plants per cross were selected), $1.85 \%$ for F3 (3 out of 162 plants per cross were selected) and $2.5 \%$ for F4 (3 out of 120 plants per cross were selected). Each selected plant constituted a family (i.e. 3 families per cross) in each generation (Figure 1). The evaluation from F2 to F4 generation was applied following the three groups of evaluation criteria previously mentioned, except the 
GCA which was calculated through the F2 generation.

Finally, seed from the selected high yielding plants of each cross of the F4 generation was established in a RCBD in dense stand with the presence of the four parents, as checks, for the comparative trial of F5 generation. The evaluation was applied with the criteria of yield heterosis and stability of performance.

\subsection{Statistical Analysis}

In the experiments for mean comparisons the t-test for independent samples from populations with different standard deviations was used with application of Cochran's approximation (Snedecor \& Cohran, 1967). Heterosis was estimated: (i) over the best parent (heterobeltiosis) and (ii) over mid parent (relative heterosis) (Fanseco \& Peterson, 1968). At the present work the mean yield of the four parents/checks was used as the expression of standard heterosis. Standard heterosis refers to the comparison of an F1 with one or more broadly cultivated varieties at the region (Virmani, 1994). The significance of relative and standard heterosis was checked with one degree of freedom comparisons.

For the isolation environment two formulas, proposed by Fasoula (2013), were estimated: (i) the Sibling line prognostic equation (s-PE) and (ii) the Plant prognostic equation (p-PE). s-PE evaluated the performance of each entry and was specified as the product of two components: a) Coefficient of Homeostasis $\mathrm{CH}=\left(\overline{x_{t}} / \mathrm{s}\right)^{2}$ where $\overline{x_{t}}$ is the mean of each treatment and $s$ is the standard deviation and b) Sibling Yield Index $s-Y I=\left(\overline{x_{t}} / \bar{x}\right)^{2}$ where $\bar{x}$ is the grand mean. s-PE was used for the correspondence of the isolation environment with solid stand. For the evaluation/ranking of single plants p-PE was determined as the product of two components: a) $\mathrm{CH}$ and b) Plant Yield Index $p-Y I=\left(x / \overline{x_{r}}\right)^{2}$ where $x$ is the yield of the plant in the center of the moving ring and $\overline{x_{r}}$ is the mean yield of the plants composing the moving ring around the plant (Figure 1). (Fasoula, 2013)

The general combining ability (GCA) was estimated for the incomplete diallel according to Griffing's (1956) diallel analysis. Analysis of variance for general and specific combining abilities was performed for the F1 and F2 generation and the genetic components were estimated for grain yield.

\section{Results}

Table 2. Ranking of $\mathrm{F}_{1}$ 's: heterosis over better parent (BP), mid parent (MP), standard heterosis (over six parents $\mathrm{SH}$ ), grain yield (g/plant GY), productivity (Sibling Yield Index, s-YI), stability (Coefficient of Homeostasis, $\mathrm{CH}$ ) and yield potential (s-PE)

\begin{tabular}{lccclccc}
\hline Genotype & BP & MP & SH & GY Mean & s-YI & CH & s-PE \\
\hline Acheron x Yecora & 3 & 5 & $1^{*}$ & $1 \mathrm{a}^{* *}$ & 1 & 6 & 5 \\
Nestos x Acheloos & $1^{*}$ & $1^{*}$ & 4 & $4 \mathrm{ab}$ & 4 & 7 & 8 \\
Nestos x Orfeas & 2 & 3 & 7 & $7 \mathrm{abc}$ & 7 & 5 & 7 \\
Nestos x Oropos & 7 & 6 & 5 & $5 \mathrm{abc}$ & 5 & 4 & 4 \\
Orfeas x Acheloos & 5 & 9 & 9 & $9 \mathrm{abcd}$ & 9 & 1 & 2 \\
Orfeas x Oropos & 10 & 10 & 10 & $10 \mathrm{bcd}$ & 10 & 10 & $10 \sqrt{ }$ \\
Oropos x Acheloos & 8 & 4 & 8 & $8 \mathrm{abcd}$ & 8 & 2 & $1 \sqrt{ }$ \\
Yecora x Acheloos & 4 & $2 *$ & $2^{*}$ & $2 \mathrm{ab}$ & 2 & 8 & $6 \sqrt{ }$ \\
Yecora x Orfeas & 9 & 8 & 6 & $6 \mathrm{abc}$ & 6 & 9 & 9 \\
Yecora x Oropos & 6 & 7 & $3^{*}$ & $3 \mathrm{ab}$ & 3 & 3 & $3 \sqrt{ }$ \\
\hline
\end{tabular}

*significant positive heterosis.

** Means followed by different letters are significantly different at the 0.05 level.

$\sqrt{ }$ selected crosses.

Modified data of F1 generation (Gogas \& Koutsika-Sotiriou, 2012) with ten F1s were compiled in Table 2. The F1s were ranked according to three heterotic patterns and to four productivity and stability indexes. Each of the pre-mentioned parameters was ranked in a scale from 1 to 10 , for higher and lower value, respectively for each F1. Accordingly, three F1s showed significant standard heterosis and were equal to best parent and mid parent values, and one surpassed significantly mid parent value. Productivity and stability indexes gave a more clear view of the 
performance of the crosses classifying them into high, medium and low yielding ones.

Only F1s with, positive general combining ability (GCA) of the parents were considered for further selection. Therefore, discarding F1s with parents with negative GCA (Table 3), a selection of three classes concerning productivity and stability i.e. high, medium and low, could be entered to the experiment. According to the ranking of the F1s with the aforementioned parameters the following were selected: a) Oropos x Acheloos (OxA) having the highest s-PE value i.e. high productivity and stability and being heterotic, b) Yecora $\mathrm{x}$ Oropos (YxO) ranking third in productivity and stability index s-PE and exhibiting significant standard heterosis, c) Yecora $\mathrm{x}$ Acheloos (YxA) which ranked sixth in productivity and stability index and exhibited significant heterosis and standard heterosis and d) Orfeas $x$ Oropos (OxO) the F1 with the lowest s-PE value and with negative heterosis over best and mid parent value.

The diallel analysis for grain yield of the F1 and F2 generation gave further insight on the genetic basis of the first generations. Mean squares of GCA and SCA were found significant for both generations, the results being in agreement with other studies (Perenzin., Corbellini, Accerbi, Vaccino, \& Borghi, 1998). The mean squares for GCA were two and three times higher in the F1 and F2 generation than for SCA effects, respectively, indicating the predominance of additive gene action (Table 3 ). However, the ratio of $\mathrm{V}_{\mathrm{GCA}}: \mathrm{V}_{\mathrm{SCA}}$ was greater than the unity $(>1)$ in the F2 generation indicating the preeminent role of additive effects for grain yield (Table 3), while in the F1 generation the variance ratio of the combining abilities was lower than the unity $(<1)$ since in F1s heterotic effects are due to dominant gene action. Since $\mathrm{V}_{\mathrm{GCA}}$ is a function of additive variance and $\mathrm{V}_{\mathrm{SCA}}$ is equal to the variance component due to dominance variance, when epistasis is assumed negligible (Bernardo, 2002), heterotic patterns in the F2 generation are more likely to be inherited in the next generations than in the F1 generation.

Table 3. General combining ability (GCA) of the parents in $\mathrm{F}_{1}$ and $\mathrm{F}_{2}$, mean squares of GCA/SCA and the variance components

\begin{tabular}{lllllll}
\hline Parents & Acheron & Yecora-E & Nestos & Orfeas & Oropos & Acheloos \\
\hline GCA F $_{1}$ & -26.72 & 13.95 & -4.2 & 4.66 & 5.36 & 6.95 \\
GCA F $_{2}$ & - & -0.6 & - & -30.01 & 50.18 & 4.38 \\
\hline
\end{tabular}

\begin{tabular}{lllll}
\hline Source & d.f $\mathrm{F}_{1}$ & $\mathrm{MS} \mathrm{F}_{1}$ & d.f $\mathrm{F}_{2}$ & $\mathrm{MS} \mathrm{F}_{2}$ \\
\hline GCA & 5 & $1640.09^{* *}$ & 3 & $2144.76^{*}$ \\
SCA & 9 & $991.89^{* *}$ & 2 & $648.85^{* *}$ \\
Error & 14 & 60.78 & 5 & 36.59 \\
\hline
\end{tabular}

*significant at $\mathrm{p} \leq 5 \%, * *$ significant at $\mathrm{p} \leq 1 \%$.

\begin{tabular}{lll}
\hline Generation & $\mathrm{F}_{1}$ & $\mathrm{~F}_{2}$ \\
\hline Var GCA & 205.011 & 536.191 \\
Var SCA & 495.946 & 324.425 \\
GCA/SCA & 0.41 & 1.65 \\
\hline
\end{tabular}

Throughout F2 to F5 generation the initial ranking of the crosses didn't remain stable except for the first and the last classified crosses. OxA, in particular, gave significantly high BP, MP and 4P values through F2 to F5 (Tables 4 and 7) outyielding all other crosses. In terms of productivity and stability OxA outyielded the rest, scoring the highest values for s-YI and $\mathrm{CH}$, with an exception in F3 generation where it was equal to YxA (Table 5). YxA performed well in $\mathrm{F} 3$ during the less productive year (Tables 4 and 5); however in F4 and F5 generation (dense stand) it was third in terms of productivity and stability. $\mathrm{YxO}$, also classified as medium yielding cross showed an increase in s-PE from F2 to F4 generation (Table 5) exhibiting significant heterosis, heterobeltiosis and standard heterosis in F5 (Table 6). Three crosses out of four (except OxO) had s-YI>1 from F1 to F4 (Tables 2 and 5) an indication of promising segregating material (Fasoula, 2008). The low yielding cross $\mathrm{OxO}$, although heterotic (non significant) in F4 and F5, in terms of productivity and stability in the isolation environment, was below the 50\% level of the highest yielding cross. 
Table 4. Estimation of heterobeltiosis (BP), relative heterosis (MP) and standard heterosis (over four checks, $\mathrm{SH}$ ) for $\mathrm{F}_{2}$ to $\mathrm{F}_{5}$ generation

\begin{tabular}{|c|c|c|c|}
\hline \multicolumn{4}{|c|}{ Generations } \\
\hline Genotype/Heterosis & $\mathrm{F}_{2}$ & $\mathrm{~F}_{3}$ & $\mathrm{~F}_{4}$ \\
\hline \multicolumn{4}{|l|}{ Oropos x Acheloos } \\
\hline BP & $13.12 \% *$ & $18.48 \% *$ & $19.74 \% *$ \\
\hline MP & $17.78 \% *$ & $23.56 \% *$ & $35.21 \% *$ \\
\hline SH & $38.62 \% *$ & $43.49 \% *$ & $37.61 \% *$ \\
\hline \multicolumn{4}{|l|}{ Yecora x Acheloos } \\
\hline BP & $-6.41 \%$ & $46.07 \% *$ & $9.91 \%$ \\
\hline MP & $6.64 \%$ & $53.91 \% *$ & $9.89 \%$ \\
\hline $\mathrm{SH}$ & $14.68 \% *$ & $62.34 \% *$ & $23.71 \% *$ \\
\hline \multicolumn{4}{|l|}{ Yecora x Oropos } \\
\hline BP & $-0.50 \%$ & $-2.51 \%$ & $14.02 \%$ \\
\hline MP & $9.34 \%$ & $6.89 \%$ & $26.40 \% *$ \\
\hline SH & $12.29 \%$ & $18.08 \% *$ & $25.67 \% *$ \\
\hline \multicolumn{4}{|l|}{ Orfeas x Oropos } \\
\hline BP & $-8.24 \%$ & $-18.04 \%$ & $16.93 \%$ \\
\hline MP & $12.00 \%$ & $5.02 \%$ & $18.08 \%$ \\
\hline $\mathrm{SH}$ & $3.55 \%$ & $-0.73 \%$ & $3.23 \%$ \\
\hline
\end{tabular}

*significant at $\mathrm{p} \leq \overline{5 \%}$

Table 5 . The yield ability of successive generations $\left(\mathrm{F}_{2}\right.$ to $\left.\mathrm{F}_{4}\right)$ of the degraded crosses and their parents for grain yield (g/plant GY), productivity (Sibling Yield Index, s-YI,), stability (Coefficient of Homeostasis, $\mathrm{CH}$ ) and yield potential (s-PE)

\begin{tabular}{|c|c|c|c|c|c|c|c|c|c|c|c|c|}
\hline Genotypes/Generattions & Mean yie & eld & & s-YI & & & $\mathrm{CH}$ & & & s-PE\% & & \\
\hline & F2 & F3 & $\mathrm{F} 4$ & $\mathrm{~F} 2$ & F3 & $\mathrm{F} 4$ & $\mathrm{~F} 2$ & F3 & $\mathrm{F} 4$ & $\mathrm{~F} 2$ & $\mathrm{~F} 3$ & $\mathrm{~F} 4$ \\
\hline Oropos x Acheloos & $66.97 a^{*}$ & $30.6 \mathrm{a}$ & $82.69 a^{*}$ & 1.66 & 1.60 & 1.61 & 6.66 & 5.03 & 8.06 & 100 & 81.36 & 100.00 \\
\hline Yecora x Acheloos & $55.4 \mathrm{bc}$ & $34.61 a^{*}$ & 74.34abc & 1.13 & 2.05 & 1.30 & 5.21 & 4.83 & 7.61 & 53.55 & 100 & 76.26 \\
\hline Yecora x Oropos & $54.25 \mathrm{bc}$ & $25.17 \mathrm{bc}$ & $75.51 \mathrm{ab}$ & 1.09 & 1.08 & 1.35 & 3.85 & 4.17 & 9.03 & 37.94 & 45.76 & 93.40 \\
\hline Orfeas x Oropos & $50.03 \mathrm{c}$ & $21.16 \mathrm{c}$ & $62.03 \mathrm{~cd}$ & 0.92 & 0.77 & 0.91 & 4.02 & 5.41 & 6.10 & 33.69 & 41.89 & 42.53 \\
\hline Parents/Year & 2009 & 2010 & 2011 & 2009 & 2010 & 2011 & 2009 & 2010 & 2011 & 2009 & 2010 & 2011 \\
\hline Acheloos & $59.2 b$ & $23.70 \mathrm{bc}$ & $69.05 \mathrm{bc}$ & 1.3 & 0.96 & 1.13 & 5.44 & 4.38 & 7.70 & 63.84 & 42.58 & 66.61 \\
\hline Orfeas & $34.82 \mathrm{e}$ & $14.48 \mathrm{~d}$ & $51.81 \mathrm{~d}$ & 0.45 & 0.36 & 0.63 & 4.97 & 8.90 & 5.22 & 33.22 & 32.28 & 25.42 \\
\hline Oropos & $54.52 \mathrm{bc}$ & $25.82 \mathrm{~b}$ & $53.26 \mathrm{~d}$ & 1.1 & 1.14 & 0.67 & 4.89 & 6.06 & 6.72 & 48.65 & 69.84 & 34.58 \\
\hline Yecora & $44.71 d$ & $21.28 \mathrm{c}$ & $66.23 \mathrm{bc}$ & 0.74 & 0.77 & 1.04 & 4.97 & 5.96 & 6.24 & 20.17 & 46.69 & 49.60 \\
\hline
\end{tabular}

* Means followed by different letters are significantly different at the 0.05 level. 
Table 6. The genetic components of diallel analysis of $F_{1}$ and $F_{2}$ for grain yield

\begin{tabular}{lll}
\hline Genetic component & $\mathrm{F}_{1}$ & $\mathrm{~F}_{2}$ \\
\hline $\mathrm{D}^{(1)}$ & 25.7411 & 135.7337 \\
$\mathrm{H} 1^{(2)}$ & 1972.187 & 1649.376 \\
$\mathrm{H}^{(3)}$ & 1571.295 & 1302.23 \\
$\mathrm{H}_{2} / 4 \mathrm{H}_{1}{ }^{(4)}$ & 0.199 & 0.197 \\
$(\mathrm{H} 1 / \mathrm{D})^{1 / 2(5)}$ & 8.753 & 3.486 \\
$\mathrm{~F}^{(6)}$ & 92.2659 & -279.683 \\
$\mathrm{kd} /(\mathrm{kd}+\mathrm{kr})^{(7)}$ & 0.6024 & 0.3522 \\
$\mathrm{H}^{(8)}$ & -11.5 & -21 \\
$\mathrm{H}_{\mathrm{b}}{ }^{2(9)}$ & 0.955 & 0.98 \\
$\mathrm{H}_{\mathrm{n}}{ }^{2(10)}$ & 0.285 & 0.528 \\
\hline
\end{tabular}

1) Additive variance; 2) Dominance variance1; 3) Dominance variance2; 4) Balance of positive and negative alleles; 5) Average degree of dominance; 6) Product of add. by dom. Effects; 7) Proportion of dominant genes; 8) Average direction of dominance; 9) Heritability for diallel in a broad sense; 10) Heritability for diallel in a narrow sense.

Furthermore the genetic components in both generations showed that the additive variance component (D) was higher in F2 generation than in F1 but relatively lower than the dominance variance components (H1 and $\mathrm{H} 2)$ for both generations (Table 6). The balance of positive and negative genes (H2/4H1) was equal to 0.199 in F1 generation and 0.197 in F2 generation (lower than 0.25) suggesting unequal mean allelic frequencies at the loci with dominant and recessive genes (Table 6). The average degree of dominance (H1/D) ${ }^{1 / 2}$ although reduced in F2 generation it was greater than the unity suggesting the presence of overdominance.

The product of additive by dominant effects (F) in F1 generation was positive denoting that dominant genes were more frequent than recessive ones while the opposite was found for F2 generation (negative value for F, Table 6). In addition the proportion of dominant genes $(\mathrm{kd} /(\mathrm{kd}+\mathrm{kr}))$ for both generations was lower than the unity reflecting an excess of recessive genes (Table 6). Average direction of dominance $(\mathrm{H})$ was negative for both F1 and F2 generation meaning that the presence of dominant genes was an inhibitory factor for increasing grain yield (Table 6). Thus, even with the indications for the presence of overdominance, the diallel analysis pointed at the selection of recessive genes for increasing grain yield, which could be easily fixed.

Estimates of variance due to genotype and due to experimental error for generations F2 to F4 were made during selection procedure. At the first cross from the classified (OxA) and at the last one $(\mathrm{OxO})$, a gradual decrease in $\sigma_{\mathrm{g}}^{2}$ was observed (Figure 2) which was anticipated due to inbreeding and to an increase in homozygosity. On the other hand, the other two classified crosses $\mathrm{YxA}$ and $\mathrm{YxO}$, gave negative values in $\sigma_{\mathrm{g}}^{2}$ in $\mathrm{F} 2$ generation which was significantly increased (in F3) and then dropped (in F4) (Figure 2).

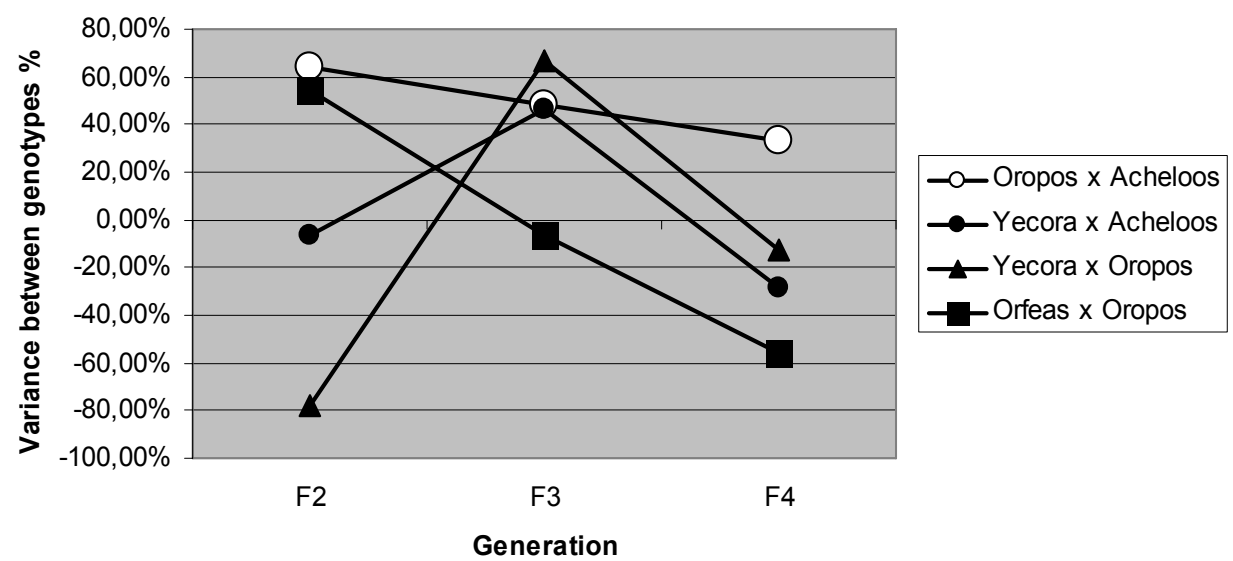

Figure 2. Depicting the genetic variance $\operatorname{cross}^{-1}$ through generations 
The results of F5 lines clarified a high yielding line derived from the cross ranked first in the classification (i.e. OxA) with the highest yielding stability. From the beginning of the selection procedure the OxA was ranked first owing to its high yield stability (high CH Table 2) and from the results of F2 evaluation it could be selected for the development of stable and high yielding F5 lines. OxA overyielded 18.43\% from the following highest yielding F5 line and $45.05 \%$ (significant supperiority) from the highest yielding 'Acheloos'. Moreover, in terms of stability it accounted for only $1.46 \%$ of the experimental error while the second ranking $\mathrm{F} 5$ line, derived from $\mathrm{YxO}$, accounted for $6.20 \%$ of the experimental error (four times higher) indicating less stable material. Besides, two more lines without significant difference in yield ability derived from the cross OxA (ranked 3rd and 4th Table 7), having also high stability performance (experimental error $2.18 \%$ and $3.22 \%$ ) Thus, high and stable F5 lines could be isolated successfully from early generations after multiple criteria assesment.

Table 7. Mean separation of the $\mathrm{F}_{5}$ lines with heterotic and stability criteria

\begin{tabular}{|c|c|c|c|c|c|c|}
\hline \multirow[b]{2}{*}{ Genotype } & \multicolumn{5}{|c|}{ Heterotic criteria } & \multirow{2}{*}{$\begin{array}{l}\text { Stability criteria } \\
\% \text { experimental error }\end{array}$} \\
\hline & BP & MP & SH & Mean & & \\
\hline Oropos x Acheloos & $45.05 \% *$ & $69.23 \% *$ & $72.93 \% *$ & 264 & $a^{* *}$ & $1.46 \%$ \\
\hline Yecora x Oropos & $54.55 \% *$ & $59.90 \% *$ & $41.05 \% *$ & 215.33 & $a b$ & $6.20 \%$ \\
\hline Oropos x Acheloos & $12.09 \%$ & $30.77 \%$ & $33.62 \%$ & 204 & $a b c$ & $2.18 \%$ \\
\hline Oropos x Acheloos & $11.36 \%$ & $29.91 \%$ & $32.75 \%$ & 202.67 & $a b c$ & $3.22 \%$ \\
\hline Yecora x Oropos & $39.23 \%$ & $44.06 \%$ & $27.07 \%$ & 194 & bcd & $18.99 \%$ \\
\hline Yecora x Acheloos & $0.73 \%$ & $14.11 \%$ & $20.09 \%$ & 183.33 & bcde & $0.80 \%$ \\
\hline Acheloos & & & & 182 & bcde & $13.54 \%$ \\
\hline Yecora x Oropos & $29.19 \%$ & $33.66 \%$ & $17.90 \%$ & 180 & bcde & $9.80 \%$ \\
\hline Orfeas X Oropos & $9.83 \%$ & $20.97 \%$ & $14.63 \%$ & 175 & bcde & $7.16 \%$ \\
\hline Orfeas X Oropos & $6.28 \%$ & $17.05 \%$ & $10.92 \%$ & 169.33 & bcdef & $15.04 \%$ \\
\hline Orfeas & & & & 159.33 & bcdef & $6.91 \%$ \\
\hline Yecora x Acheloos & $-21.43 \%$ & $-11.00 \%$ & $-6.33 \%$ & 143 & cdef & $1.38 \%$ \\
\hline Yecora & & & & 139.33 & cdef & $11.32 \%$ \\
\hline Oropos & & & & 130 & def & $0.84 \%$ \\
\hline Orfeas X Oropos & $-22.59 \%$ & $-14.75 \%$ & $-19.21 \%$ & 123.33 & ef & $0.28 \%$ \\
\hline Yecora x Acheloos & $-42.86 \% *$ & $-35.27 \%$ & $-31.88 \%$ & 104 & $\mathrm{f}$ & $0.86 \%$ \\
\hline
\end{tabular}

* Significant at $\mathrm{p}=5 \%$.

**Means followed by different letters are significantly different at the 0.05 level.

\section{Discussion}

Early generation selection in bread wheat breeding is a challenging procedure since there is no specific methodology which can accurately discriminate promising genetic material. Heterotic patterns are typically preferred than non-heterotic ones in the selection of F1, as they are likely to give transgressive segregants (Briggle, Cox, \& Hayes, 1967; Nass, 1979; Gouli \& Koutsika, 1999; Corbellini, Perenzin, Accerbi, Vaccino, \& Borghi, 2002). Therefore the highly significant values of better parent and mid parent heterosis of an F1 consists a priority to be entered to selection procedure (Singh et al., 2004). On the other hand, significant standard heterosis represents higher performance than the mean yield of well-adapted varieties and it may be considered a practical point of view as it represents its cultivation performance (Alam et al., 2004). At the present study ten out of ten F1s exhibited positive heterotic patterns thus, when dealing with a large number of crosses heterosis alone cannot determine which of them should remain in the selection procedure. The risks of selecting crosses based only on data from F1 generation due to dominance effects have already been mentioned (Gogas \& Koutsika-Sotiriou, 2012).

Many researchers have proposed positive GCA of the parents of a cross as a selection criterion (Borghi \& Perenzin, 
1994; Barnard, Labuschagne, \& Van Niekerk, 2002; Corbellini et al., 2002; Rebetzke, Richards, Condon, \& Farquhar, 2006; Gogas \& Koutsika-Sotiriou, 2012) and eventually a number of heterotic crosses can be discarded. Since high and stable yield is the aim of a wheat breeder, a classification concerning these parameters should be taken into consideration. Genes controlling productivity and stability can be approached through certain indexes (i.e. CLR, CH etc). High stability in F1/F2 can be interpreted as high heritability or as a low load of deleterious genes (Fasoula, 2008). The product of productivity and stability parameters classified the crosses to be evaluated in three classes i.e. high, medium and low.

According to this logic four classified crosses were chosen: the first and the last one were in accordance to Nass (1979) suggestions that high yielding F1s give better F4s than the low yielding ones. For medium yielding crosses i.e. YxA and YxO, one may clarify the following: The YxA significantly outyielded four parents value, from F2 to F4 generation; however in F5 generation, its performance was equal to the lowest yielding cross, so it may be characterized as poor material. The $\mathrm{YxO}$ outyielded four parents value in F3 and F4 generation while in F5 generation its performance exhibited a significant heterobeltiosis, relative and standard heterosis. Searching for help in GCA data of their parents, 'Yecora' and 'Orfeas' had negative values while 'Oropos' and 'Acheloos' had positive values. Thus the highest yielding F5 line derived from varieties with positive GCA in F2 and the lowest yielding F5 line derived from varieties with negative GCA in F2. From the medium yielding crosses $\mathrm{YxO}$ had as parents 'Yecora' (with slightly negative GCA) and 'Oropos' (with the highest GCA in F2), which eventually led to a high yielding F5. On the other hand, YxA with 'Yecora' and 'Acheloos', the latter having positive GCA but approximately $8.7 \%$ the GCA of 'Oropos', ended up eventually with a non promising F5. According to Soriano Viana (2000) such a variation in GCA values indicates strong differences in allele frequencies and genetic divergence among the diallel parents for the trait under study.

The diallel analysis showed an anticipated lower frequency of dominant genes in F2 generation while overdominance was assumed for both F1 and F2. Overdominance hypothesis states that heterosis is due to inter allelic interactions and it isn't fixable (Singh et al., 2004). In the case that single gene overdominance is important in heterosis then it is impossible to obtain homozygotes as vigorous as heterozygotes. However, the fixation of dominant genes is controversial in the sense that disadvantageous overdominant genes have a low probability of fixation whereas advantageous overdominant genes are more probable to be fixed (Masatoshi \& Roychoudhury, 1973). Furthermore, there is substantial evidence that heterosis is not controlled by a single locus alone, even if that locus behaves in a dominant or overdominant way (Yu., Hiatt, Chan, Sweeney, \& Dawe, 1997; Monforte \& Tanksley, 2000). Moreover, overdominance can be in fact pseudo-overdominance, as linkage and epistasis among multiple loci may contribute in the expression of heterosis (Budak, 2002). At the present study, besides the presence of overdominance, an excess of recessive alleles were also found. Since the direction of dominance was negative, selection for recessive genes may increase grain yield, a situation that can be easily fixed with the appropriate methodology applied, which discriminated those genotypes. Additionally, the extremely low selection intensity that was applied (ranging from $2.7 \%$ and $1.04 \%$ for F1 and F2 up to $1.85 \%$ and $2.5 \%$ for F3 and F4 respectively) favored them as homozygosity was increased.

The main issue emerged from the present study was the significance of agronomic stability in classified crosses. Their catalytic role overshadowed all other multiple criteria. Control could be achieved by a plethora of recessive alleles that contributed to the late generations for elite lines. In terms of agronomic stability the cross OxA maintained positive values of $\sigma_{\mathrm{g}}^{2}$ through inbreeding from F2 to F4 (Figure 2). The increase of $\sigma_{\mathrm{e}}^{2}$ (residual percentage of $\sigma_{\mathrm{g}}^{2}$ ) in $\mathrm{F} 3$ and $\mathrm{F} 4$ generations is due to the increase of homozygosity rather than environmental effects thus rendering OxA both stable and productive. Indeed, the exploitation of a positive GE-interaction-based package was the core of the success of the Green Revolution (Simmonds, 1979; Simmonds, 1991). All the other crosses showed negative values of $\sigma_{\mathrm{g}}^{2}$ in at least two of the three generations of selection.

Numerous scholars dealt with the issue of the negative variance components. Some, on one hand, supported the exact reporting without changing. Others, on the other hand, kept a different line, insisting on negative estimates being tagged as zero (Littell, Stroup, \& Freund, 2002) since variances cannot be negative by definition (Brown \& Mosteller, 1991). On the other hand a negative variance component might be a useful diagnostic tool (Hocking, 1983; Searle, Casella, \& McCulloch, 1992) especially in the interpretation of the biological significance of this value. The results of the present study indicated negative values of $\sigma_{\mathrm{g}}^{2}$ for three crosses, namely YxA, YxO and OxO. From a genetic point of view this could be interpreted as a "masking" effect of the environment over the genotype, which means significant genotype by environment interaction as the generations were evolving, exhibiting negative values of $\sigma_{\mathrm{g}}^{2}$. Finally, the fluctuation, occurred in $\sigma_{\mathrm{g}}^{2}$ value in the two of them (YxA and YxO), possibly showed that these crosses were less affected from the genotype by environment interaction in a stressful year. 
Studying a couple of genetic parameters that are used in the evaluation of segregating generations in wheat breeding, one may conclude the following: The isolation environment of selection clarified the whole procedure owing to the fact that phenotyping achieve genotyping in the differentiation of the crosses (Newton et al., 2010), discriminated and predicted successfully the elite F5 lines. The low yielding, non heterotic crosses in F1 and F2 generation fail to succeed promising lines in late generations and may be ignored in a breeding program with a lot of crosses. The standard check heterosis suggested more steadily crosses with high yield potential, under the prerequisite of the general combining ability in F1 and F2 generation; the genetic components provide further insight for the genetic background of the parents and could help in the choice of source material. Therefore, as an epilogue, an appropriate methodology which estimates productivity and stability, heterotic effects and the general combining ability of the parents, may be a prosperous leader for a successful outcome.

\section{References}

Alam, M. F., Khan, M. R., Nuruzzaman, M., Parvez, S., Swaraz, A. M., Alam, I., \& Ahsan, N. (2004). Genetic basis of Heterosis and Inbreeding Depression in Rice (Oryza sativa L.). J. Zhejiang Univ. Sci., 5(4), 406-411. http://dx.doi.org/10.1631/jzus.2004.0406

Ali Avci, E. C. M. (2005). Combining ability and heterosis for grain yield and some yield components in pea (Pisum sativum L.). Pak. J. Biol. Sci., 8, 1447-1452. http://dx.doi.org/10.3923/pjbs.2005.1447.1452

Barnard, A. D., Labuschagne, M. T., \& Van Niekerk, H. A. (2002). Heritability estimates of bread wheat quality traits in The Western Cape Province of South Africa. Euphytica, 127, 115-122. http://dx.doi.org/10.1023/A:1019997427305

Bernardo, R. (2002). Breeding for quantitative traits in plants. Woodbury, MN: Stemma Press.

Borghi, B., \& Perenzin, M. (1994). Diallel analysis to predict heterosis and combining ability for grain yield, yield components and bread-making quality in bread wheat (Triticum aestivum). Theor Appl Genet, 89, 975-981. http://dx.doi.org/10.1007/BF00039872

Borghi, B., Perenzin, M., \& Nash, R. J. (1988). Agronomic and qualitative characteristics of ten bread wheat hybrids produced a chemical hybridizing agent. Euphytica, 39, 185 - 194.

Briggle, L. W., Cox, F. L., \& Hayes, R. N. (1967). Performance of spring wheat hybrids, F2, F3 and parent varieties at five population levels. Crop Sci., 7, 6465 - 6470.

Brown, C., \& Mosteller, F. (1991). Components of variance. In D. C. Hoaglin, F. Mosteller, \& J. W. Tukey (Eds.), Fundamentals of exploratory analysis (pp. 59-84). Wiley, New York. http://dx.doi.org/10.1002/9780470316832.ch9

Budak, H., Cesurer, L., Bolek, Y., Dokuyuku, T., \& Akkaya, A. (2002). Understanding of heterosis. J. Sci. Eng., 5, 68-75.

Corbellini, M., Perenzin, M., Accerbi, M., Vaccino, P., \& Borghi, B. (2002). Genetic diversity in bread wheat, as revealed by coefficient of parentage and molecular markers, and its relationship to hybrid performance. Euphytica, 123, 273-285. http://dx.doi.org/10.1023/A:1014946018765

Fanseco, S., \& Peterson, F. L. (1968). Hybrid vigor in a seven parent diallel cross in common wheat (T. aestivum L.). Crop Sci., 8, 85-88. http://dx.doi.org/10.2135/cropsci1968.0011183X000800010025x

Fasoula, V. A. (2008). Modern variety breeding for present and future needs. Proceedings of the 18th Eucarpia general congress (pp. 361-365). Spain.

Fasoula, V. A. (2013). Prognostic breeding: A new paradigm for crop improvement. In J. Janik (Ed.), Plant Breeding Reviews (Vol. 37, pp. 297-347). John Wiley and Sons.

Fasoula, V. A., \& Fasoula, D. A. (2000). Honeycomb breeding: Principles and applications. In J. Janick (Ed.), Plant Breeding Reviews (Vol. 18, pp. 177-250). John Wiley and Sons.

Fasoulas, A. C. (1973). A new approach to breeding superior yielding varieties (Publ. 3). Department of Genetics and Plant Breeding, Aristotle University of Thessaloniki, Greece.

Fasoulas, A. C. (1977). Field designs for genotypic evaluation and selection (Publ. 7). Department of Genetics and Plant Breeding, Aristotle University of Thessaloniki, Greece.

Fasoulas, A. C. (1988). The honeycomb methodology of plant breeding. Department of Genetics and Plant Breeding, Aristotle University of Thessaloniki, Greece. 
Gogas, C., \& Koutsika-Sotiriou, M. (2012). Phenotyping and genotyping through F1 and F2 generation the promising crosses. Int. J. Plant Breed. Genet., 6, 217-227. http://dx.doi.org/10.3923/ijpbg.2012.217.227

Gouli-Vardinoudi, E., \& Koutsika-Sotiriou, M. (1999). Early generation testing for isolating promising crosses in bread wheat. Rachis, 18(2), 25-30.

Griffing, B. (1956). Concept of general and specific combining ability in relation to diallel crossing systems. Aust. J. of Biol. Sci., 9, 463-493.

Hallauer, A. R., \& Miranda, J. B. (1988). Qualitative genetics in maize breeding (2nd ed.). Iowa Univ. Press Ames.

Hinson, K., \& Hanson, W. D. (1962). Competition studies in soybeans. Crop Sci, 2, 117-123. http://dx.doi.org/10.2135/cropsci1962.0011183X000200020010x

Hocking, R. R. (1983). A Diagnostic Tool for Mixed Models with Applications to Negative Estimates of Variance Components. In Proceedings of the Eighth Annual SAS Users Group International Conference. Cary, NC: SAS Institute Inc.

Khalifa, M. A., \& Qualset, C. O. (1975). Intergenotypic competition between tall and dwarf wheats: mechanical mixtures. Crop Sci., 14, 795-799. http://dx.doi.org/10.2135/cropsci1974.0011183X001400060005x

Kotzamanidis, S. T., Lithourgidis, A. S., Mavromatis, A. G., Chasioti, D. I., \& Roupakias, D. G. (2008). Prediction criteria of promising F3 populations in durum wheat: A comparative study. Field Crops Res., 107, 257-264. http://dx.doi.org/10.1016/j.fcr.2008.02.012

Kotzamanidis, S. Th., \& Roupakias, D. G. (2004). Plant density affects the reliability of using F1 and F2 yield to predict F3 yield in barley. Aus. J. Agric. Res., 55, 961-965. http://dx.doi.org/10.1071/AR03235

Koutsika-Sotiriou, M., \& Traka-Mavrona, E. (2008). Snap Bean. In J. Prohens \& F. Nuez (Eds.), Vegetables II: Fabaceae, Liliaceae, Solanaceae and Umbelliferae (pp. 27-83). Springer. http://dx.doi.org/10.1007/978-0-387-74110-9_2

Lamkey, K. R., Schnicker, B. J., \& Melchinger, A. E. (1995). Epistasis in an elite maize hybrid and choice of generation for inbred line development. Crop Sci., 35, 1972-1981. http://dx.doi.org/10.2135/cropsci1995.0011183X003500050004x

Littell, R. C., Stroup, W. W., \& Freund, R. J. (2002). SAS for Linear Models (4th ed.). SAS Institute, Inc.

Masatoshi, N., \& Roychoudhury, A. K. (1973). Probability of fixation and mean fixation time of an overdominant mutation. Genetics, 74, 371-380.

Monforte, A. J., \& Tanksley, S. D. (2000). Fine mapping of a quantitative trait locus (QTL) from Lycopersicon hirsutum chromosome 1 affecting fruit characteristics and agronomic traits: breaking linkage among QTLs affecting different traits and dissection of heterosis for yield. Theor. Appl. Genet., 100, 471-479. http://dx.doi.org/10.1007/s001220050061

Nass, H. G. (1979). Selecting superior spring wheat crosses in early generations. Euphytica, 28, 161-167. http://dx.doi.org/10.1007/BF00029186

Newton, A. C., Akar, T., Baresel, J. P., Bebeli, P. J., Bettencourt, E., Bladenopoulos, K. V., ... Vaz Patto, M. C. (2010). Cereal Landraces: An essential resource for the future of modern agriculture. A review. Agron. Sustain. Dev., 30(2), 237-269. http://dx.doi.org/10.1051/agro/2009032

Papapdopoulos, I., Tokatlidis, I., Tamoutsidis, E., Koutsika Sotiriou, M., \& Koutroubas, S. (2007). Crop Yield Potential Estimation under Too Low Density in Dry Bean Genotypes. Int. J. Plant Breed. Genet., 1(2), 75-81. http://dx.doi.org/10.3923/ijpbg.2007.75.81

Perenzin, M., Corbellini, M., Accerbi, M., Vaccino, P., \& Borghi, B. (1998). Bread wheat: F1 hybrid performance and parental diversity estimates using molecular markers. Euphytica, 100, 273-279. http://dx.doi.org/10.1023/A:1018324811038

Rebetzke, G. J., Richards, R. A., Condon, A. G., \& Farquhar, G. D. (2006). Inheritance of carbon isotope discrimination in bread wheat (Triticum aestivum L.). Euphytica, 150(1-2), 97-106. http://dx.doi.org/10.1007/s10681-006-9097-4

Roupakias, D., Zesopoulou, A., Kazolea, S., Dalkalitses, G., Mavromatis, A., \& Lazaridou, T. (1997). Effectiveness of early generation selection under two plant densities in faba bean (Vicia faba L.). Euphytica, 93, 63-70. http://dx.doi.org/10.1023/A:1002960208864 
Schnell, F. W. (1983). Problème der Elternwahl-Ein Überblick. In Arbeitstagung der Arbeitsgemeinschaft der Saatzuchleiter in Gumpenstein, Austria (pp. 1-11). Verlag and Druck der Bundesanstalt fur alpenlanddische Landwirtschaft. Gumpenstein, Austria.

Searle, S. R., Casella, G., \& McCulloch, C. E. (1992). Variance Components. New York: John Wiley \& Sons. http://dx.doi.org/10.1002/9780470316856

Shebeski, L. H, \& Evans, L. E. (1973). Early generation selection for wide adaptability in the breeding program. 4th International wheat genetics symposium (pp. 587-593). Columbia.

Simmonds, N. W. (1979). Principles of crop improvement. Longman, London, U.K. http://dx.doi.org/10.1007/BF02190624

Simmonds, N. W. (1991). Selection for local adaptation in a plant breeding program. Theor. Appl. Genet., 82, 363-367.

Singh, H., Sharma, N., \& Sain, R. S. (2004). Heterosis studies for yield and its components in bread wheat over environments. Hereditas, 141, 106 - 114. http://dx.doi.org/10.1111/j.1601-5223.2004.01728.x

Snedecor, G. W., \& Cohran, W. G. (1967). Statistical methods (6th ed.). The State University Press, Ames Lowa, USA.

Soriano Viana, J. M. (2000). The parametric restrictions of the Griffing diallel analysis model: combining ability analysis. Genet. Mol. Biol., 23, 877-881. http://dx.doi.org/10.1590/S1415-47572000000400029

Virmani, S. S. (1994). Heterosis and Hybrid Rice Breeding. Springer-Verlag, Berlin Heidelberg, Germany. http://dx.doi.org/10.1007/978-3-642-85115-5

Yu, H. G., Hiatt, E. N., Chan, A., Sweeney, M., \& Dawe, R. K. (1997). Neocentromere-mediated chromosome movement in maize. J. Cell Biol., 139, 831-840. http://dx.doi.org/10.1083/jcb.139.4.831

\section{Copyrights}

Copyright for this article is retained by the author(s), with first publication rights granted to the journal.

This is an open-access article distributed under the terms and conditions of the Creative Commons Attribution license (http://creativecommons.org/licenses/by/3.0/). 